\title{
Regulation of follistatin gene expression in the ovary and in primary cultures of porcine granulosa cells
}

\author{
C. E. Lindsell ${ }^{1 *}$, V. Misra ${ }^{2}$ and B. D. Murphy ${ }^{1 \dagger}$ \\ ${ }^{1}$ Department of Obstetrics and Gynecology, University of Saskatchewan, Saskatoon, \\ Saskatchewan, Canada S7N OWO; and ${ }^{2}$ Department of Veterinary Microbiology, University of \\ Saskatchewan, Saskatoon, Saskatchewan, Canada S7N OWo
}

\begin{abstract}
Experiments were designed to test the hypotheses that (1) follistatin gene expression in granulosa cells is regulated during follicular growth, and (2) that alteration of follistatin mRNA concentration can be hormonally induced in primary cultures of porcine granulosa cells. RNA isolated from granulosa cells from small ( $1-3 \mathrm{~mm}$ diameter), medium $(3-5 \mathrm{~mm}$ ) and large $(>5 \mathrm{~mm})$ follicles of prepubertal and postpubertal sows was analysed by hybridization to a porcine follistatin cDNA probe. Amounts of follistatin mRNA increased with follicular diameter, but no differences in follicular follistatin mRNA were detected between prepubertal and postpubertal sows. Treatment of cultured porcine granulosa cells with FSH or LH for $20 \mathrm{~h}$ stimulated follistatin mRNA concentration by a factor of two (100 ng FSH ml ${ }^{-1}$ ) and a factor of 1.5 (10 $\left.\mathrm{ng} \mathrm{LH} \mathrm{ml}^{-1}\right)$, respectively, over untreated controls. Treatment of cultured granulosa cells with $200 \mathrm{ng} \mathrm{FSH} \mathrm{ml}^{-1}, 200 \mathrm{ng} \mathrm{LH} \mathrm{ml}^{-1}$, $10 \mu \mathrm{mol}$ dibutyryl cAMP $\mathrm{l}^{-1}, 30 \mu \mathrm{mol}$ forskolin $\mathrm{l}^{-1}$ and $100 \mathrm{ng}$ cholera toxin $\mathrm{ml}^{-1}$ stimulated follistatin mRNA accumulation in granulosa cells by factors of $4.9,3.7,1.6,13.7$ and 3.5, respectively, compared with control cultures. Stimulation of follistatin mRNA accumulation in cultured granulosa cells by dibutyryl cAMP $\left(30,100\right.$ and $300 \mu \mathrm{mol} \mathrm{l}^{-1}$ ) and forskolin $\left(3,10\right.$ and $\left.100 \mu \mathrm{mol} \mathrm{l}^{-1}\right)$ was dose dependent. FSH and forskolin induced time-dependent increases in follistatin mRNA concentration in cultured granulosa cells, with maximal induction occurring $72 \mathrm{~h}$ after treatment (a factor of 4.5 for FSH and 15.5 for forskolin). These results demonstrate that (1) increased follistatin mRNA in granulosa cells is associated with increased follicular diameter, (2) increased follistatin mRNA in cultured porcine granulosa cells can be induced by gonadotrophins, and (3) the gonadotrophininduced increase in follistatin mRNA accumulation in cultured granulosa cells can be mimicked by agents that increase intracellular cAMP concentrations.
\end{abstract}

\section{Introduction}

Follistatin is an ovarian glycoprotein that can suppress FSH release from anterior pituitary cells in vitro (Robertson et al., 1987; Ueno et al., 1987). Although follistatin was initially isolated from bovine and porcine follicular fluids, mRNA for follistatin is found in many tissues, including the ovary, kidney, brain (Shimasaki et al., 1989), decidual tissue (Kaiser et al., 1990), testis, adrenal, thymus, pancreas, gut, heart, uterus, skeletal muscle, lung (Michel et al., 1990) and pituitary (Gospodarowicz and Lau, 1989; Michel et al., 1990), indicating that follistatin activity may not be restricted to the reproductive system. Follistatin is structurally unrelated to inhibins and activins (Esch et al., 1987; Shimasaki et al., 1988; Shimasaki et al.,

*Present address and correspondence: Department of Biological Chemistry, UCLA School of Medicine, 10833 Le Conte Ave, Los Angeles, CA 900241737, USA.

†Present address: Centre de récherche en réproduction animale, Université de Montréal, St-Hyacinthe, Québec, Canada.

Received 20 July 1993.
1989). Nevertheless, a relationship among these putative ovarian FSH-regulatory peptides was suggested by the discovery that follistatin binds activin in the ovary (Nakamura et al., 1990) and pituitary (Kogawa et al., 1991). Follistatin was subsequently demonstrated to bind both activin and inhibin by associating with the common $\beta$ subunit of these proteins (Shimonaka et al., 1991).

In addition to effects on the pituitary and possible autocrine effects on granulosa cell physiology (Shukovski et al., 1991), follistatin may function as a modulator or inhibitor of activin (DePaolo et al., 1991), which stimulates FSH release from cultured pituitary cells (Ling et al., 1986) and has effects upon differentiation in an erythroid cell line (Eto et al., 1987; Broxmeyer et al., 1988), in P19 teratoma cells (Schubert et al., 1990), and in an embryonal carcinoma cell line (Van den Eijnden-Van Raaij et al., 1991). This contention suggests that follistatin and activin may have a regulatory role in differentiative processes in a variety of cell types (DePaolo et al., 1991).

Follistatin mRNA is most abundant in the granulosa cells of growing secondary and tertiary follicles from immature rat 
ovaries (Shimasaki et al., 1989), suggesting that follistatin may be differentially expressed during follicular growth. In bovine ovaries, follistatin transcripts are found in granulosa cells from all antral follicles, reaching highest concentration in preovulatory follicles (Shukovski et al., 1992). The differential expression of follistatin mRNA in granulosa cells of growing follicles suggests that factors involved in follicular development may regulate follistatin gene expression. Furthermore, exogenous gonadotrophins upregulate ovarian follistatin mRNA concentration in vivo (Shimasaki et al., 1989). This finding implies that expression of the follistatin gene may be hormonally regulated.

The purpose of this study was to determine whether steady-state follistatin mRNA concentrations change during growth of antral follicles in pigs. In addition, primary cultures of porcine granulosa cells were used to investigate the regulation of follistatin gene expression by gonadotrophins and cyclic AMP (cAMP).

\section{Materials and Methods}

\section{Isolation of porcine $c D N A$ by reverse transcription $P C R$}

Oligonucleotide primers were designed to amplify a region of the porcine follistatin cDNA sequence from the ATG initiation codon to nucleotide 1023 based on the porcine cDNA sequence published by Esch et al. (1987), and incorporating a BamHI restriction enzyme recognition site at each end to facilitate cloning. Primer sequences were located in different exons to allow discrimination between amplification of cDNA and any contaminating genomic DNA. The following oligonucleotide primers were made on an Applied Biosystems synthesizer: 5'GGATCCATGGTCCGTCCCAAGCAC 3 ' and 5'GGATCCTCAGTAGTCCTGGTCTTC 3'. Total RNA was isolated from $2 \mathrm{~g}$ of ovarian tissue from an adult sow by the guanidinium isothiocyanate-caesium chloride method (Kingston, 1989).

Total RNA was reverse transcribed (RT) using the following reaction conditions in $25 \mu \mathrm{l}$ at $42^{\circ} \mathrm{C}$ for $1 \mathrm{~h}: 50 \mu \mathrm{g}$ total RNA, $0.5 \mu \mathrm{g}$ oligo $\mathrm{dT}_{15}$ primer, $10 \mathrm{mmol}$ dithiothreitol $\mathrm{l}^{-1}$ (Sigma Chemical Co., St Louis, MO), $1 \mathrm{mmol} \mathrm{\textrm {l } ^ { - 1 }}$ each of dATP, dCTP, dGTP and dTTP (Pharmacia, Baie d'Urte, Quebec), $8000 \mathrm{U}$ RNAsin ribonuclease inhibitor (Fisher/Promega, Nepean), $4 \mathrm{mmol}$ sodium pyrophosphate $\mathrm{l}^{-1}, 50 \mathrm{mmol}$ Tris$\mathrm{HCl} \mathrm{I}^{-1}, \mathrm{pH} 8.3,75 \mathrm{mmol} \mathrm{KCl} \mathrm{I}{ }^{-1}, 10 \mathrm{mmol} \mathrm{MgCl}_{2} \mathrm{l}^{-1}$, $0.5 \mathrm{mmol}$ spermidine $\mathrm{I}^{-1}$ (Sigma Chemical Co.) and $20 \mathrm{U}$ AMV reverse transcriptase (Fisher/Promega). Five microlitres of this reaction was added to a PCR mixture in $50 \mu \mathrm{l}$ as follows: $0.2 \mathrm{mmol} \mathrm{l}^{-1}$ each of dATP, dCTP, dGTP and dTTP, $10 \mathrm{mmol}$ Tris- $\mathrm{HCl} \mathrm{l}^{-1}, \mathrm{pH} 8.3,50 \mathrm{mmol} \mathrm{KCl} \mathrm{l}^{-1}, 1.5 \mathrm{mmol} \mathrm{MgCl} \mathrm{I}^{-1}$, $0.01 \%(\mathrm{w} / \mathrm{v})$ gelatin, $2.5 \mathrm{U}$ Taq DNA polymerase (Perkin Elmer Cetus, Norwalk), 50 pmol each primer. Twenty-five PCR cycles were conducted at $94^{\circ} \mathrm{C}$ for $1.5 \mathrm{~min}, 56^{\circ} \mathrm{C}$ for $2 \mathrm{~min}$, then $72^{\circ} \mathrm{C}$ for $2 \mathrm{~min}$, extending the $72^{\circ} \mathrm{C}$ period for $15 \mathrm{~s}$ each cycle.

The RT-PCR product was ligated into the BamHI site of the plasmid pGEM3Zf( - ) (Fisher/Promega). The identity of the cloned cDNA was confirmed by DNA sequencing and restriction endonuclease mapping using internal BgIII and PstI recognition sites. The cloned follistatin cDNA fragment hybridized to a single $2.5 \mathrm{~kb}$ species of RNA in porcine granulosa cells, in agreement with a previous report of follistatin mRNA in porcine ovarian tissue (Shimasaki et al., 1988).

\section{Porcine granulosa cell culture}

Granulosa cell culture medium consisted of minimum essential medium (MEM) containing $0.1 \mathrm{mmol}$ MEM non-essential amino acids $1^{-1}, 25 \mathrm{mmol}$ Hepes $1^{-1}, 26 \mathrm{mmol} \mathrm{NaHCO} l^{-1}$, $0.06 \mathrm{~g}$ benzylpenicillin $\mathrm{l}^{-1}, 0.1 \mathrm{~g}$ streptomycin sulfate $\mathrm{l}^{-1}$ (all from Gibco/BRL, Burlington), and $1 \mathrm{mmol} \mathrm{NaOH}{ }^{-1}$ (Sigma Chemical $\mathrm{Co}$.). Ovaries were collected from immature pigs at a local abattoir and transported to the laboratory in sterile, ice-cold saline containing $0.06 \mathrm{~g}$ benzylpenicillin $\mathrm{l}^{-1}$ and $0.1 \mathrm{~g}$ streptomycin sulfate $1^{-1}$. Follicular fluid was aspirated from $3-5 \mathrm{~mm}$ diameter follicles using a 21 gauge needle and syringe. Follicular membranes were dissected from the ovaries using fine forceps, and granulosa cells were scraped from these membranes with a scalpel. Cells were dispersed by trituration with a $20 \mathrm{ml}$ syringe and then filtered through sterile steel mesh $(0.14 \mathrm{~mm}$ mesh; Sigma Chemical Co.). Cells were washed twice in culture medium, counted and plated at a density of $1 \times 10^{6}$ cells $\mathrm{ml}^{-1}$ in Falcon six-well tissue culture plates (Becton Dickinson, Lincoln Park, NJ) in culture medium containing $10 \%$ heat-inactivated fetal bovine serum. After incubation for $48 \mathrm{~h}$ in $95 \%$ humidified air with $5 \% \mathrm{CO}_{2}$ at $37^{\circ} \mathrm{C}$, medium was replaced with culture medium without serum. Cells were incubated for a further $48 \mathrm{~h}$, after which time the medium was changed and treatments added. After the treatment period, medium was removed and stored at $-20^{\circ} \mathrm{C}$.

\section{RNA isolation}

Cultured granulosa cells were lysed in $4 \mathrm{~mol}$ guanidinium isothiocyanate $\mathrm{l}^{-1}, 20 \mathrm{mmol}$ sodium acetate $\mathrm{l}^{-1}, 0.2 \mathrm{mmol}$ dithiothreitol $1^{-1}, 0.5 \% \mathrm{~N}$-lauryl sarcosine (Sigma Chemical $\mathrm{Co}$.), then triturated through a 21 gauge needle, layered onto a gradient of $5.7 \mathrm{~mol}$ caesium chloride $1^{-1}$, and centrifuged at $174000 \mathrm{~g}$ for $20 \mathrm{~h}$ at $22^{\circ} \mathrm{C}$. The RNA pellet was dissolved in $10 \mathrm{mmol}^{\text {Tris }}-\mathrm{Cl} \mathrm{l}^{-1}, \mathrm{pH} 7.4,5 \mathrm{mmol}$ EDTA $\mathrm{l}^{-1}, 1 \%$ sodium dodecyl sulfate (SDS), precipitated twice with 0.1 volume of 3 mol sodium acetate $\mathrm{I}^{-1}$ and two volumes of absolute ethanol, dried under vacuum, then dissolved in diethylpyrocarbonate-treated distilled water and stored at $-70^{\circ} \mathrm{C}$. Concentration of nucleic acid was determined by measurement of absorbance at $260 \mathrm{~nm}$.

\section{Northern and slot blot hybridizations}

For northern blot analysis, RNA was separated on $1 \%$ agarose formaldehyde gels, then stained with ethidium bromide (Sambrook et al., 1989). The RNA was transferred to a nylon membrane (Hybond-N: Amersham, Oakville, Ontario) by capillary transfer overnight in $10 \times$ SSC $\left(1 \times \mathrm{SSC}=150 \mathrm{mmol} \mathrm{NaCl} \mathrm{l}^{-1}, 15 \mathrm{mmol}\right.$ trisodium citrate $\left.1^{-1}, \mathrm{pH} 7.0\right)$.

For slot blot analyses, $6 \mu \mathrm{g}$ total RNA in $50 \mu \mathrm{l}$ water was heated to $65^{\circ} \mathrm{C}$ for $10 \mathrm{~min}$ in $150 \mu \mathrm{l}$ denaturing solution consisting of $98 \mu \mathrm{l}$ deionized formamide, $32 \mu \mathrm{l} 37 \%$ formaldehyde and $20 \mu \mathrm{l} 10 \times$ MOPS buffer $(0.2 \mathrm{~mol} 3$-[ $\mathrm{N}$-morpholino] propanesulphonic acid $\mathrm{l}^{-1}, 0.5 \mathrm{~mol}$ sodium acetate $\mathrm{l}^{-1}$, 
$\mathrm{pH} 7.0,0.01 \mathrm{~mol}^{2}$ sodium EDTA $\mathrm{I}^{-1}$ ). An equal volume of ice-cold $20 \times$ SSC was added to the samples, which were then applied to a nylon membrane using a slot blot manifold (Bio-Rad, Mississauga).

RNA was cross-linked to nylon membranes with UV light using a UV Stratalinker 2400 (Stratagene, La Jolla, CA). The hybridization procedure consisted of rinsing the membrane in $6 \times \operatorname{SSPE}\left(1 \times\right.$ SSPE $=180 \mathrm{mmol}$ sodium chloride $1^{-1}, 10 \mathrm{mmol}$ sodium phosphate $\mathrm{l}^{-1}, 1 \mathrm{mmol}$ EDTA $\mathrm{l}^{-1}, \mathrm{pH} 7.4$ ), then prehybridizing for $\mathrm{Ih}$ at $65^{\circ} \mathrm{C}$ in hybridization solution $(5 \times$ SSPE, $5 \times$ Denhardt's solution: $0.5 \%$ SDS, $10 \%$ dextran sulfate, $200 \mu \mathrm{g}$ denatured salmon sperm DNA ml ${ }^{-1}$, Sigma Chemical Co.). The membrane was then incubated at $65^{\circ} \mathrm{C}$ overnight in hybridization solution containing denatured $\left[{ }^{32} \mathrm{P}\right]-$ labelled follistatin cDNA or human $\gamma$ actin cDNA (labelled to a specific activity of between 1.5 and 3.0 d.p.m. $\mu \mathrm{g}^{-1} \mathrm{DNA}$ ), which was used as an internal control for RNA loading. Membranes were washed twice with $2 \times$ SSPE $0.1 \%$ SDS at room temperature and twice with $0.1 \times \mathrm{SSPE}, 0.1 \% \mathrm{SDS}$ at $65^{\circ} \mathrm{C}$ for $15 \mathrm{~min}$ per wash. Blots were subjected to autoradiography using Kodak XAR-5 film. Autoradiographs were scanned with an LKB Ultro-Scan laser densitometer (Pharmacia, Baie D'Urte, Quebec). Slot blot data were expressed as arbitrary densitometric units for follistatin mRNA relative to $\gamma$ actin mRNA.

\section{Progesterone radioimmunoassay}

Cell culture medium was assayed for progesterone content without prior extraction. Progesterone concentrations were determined by liquid-phase radioimmunoassay (Rajkumar et al., 1985) using a rabbit antiserum against 4-pregnenII $\alpha$-ol 3, 20-dione hemisuccinate-BSA (NC Rawlings, Department of Veterinary Physiological Sciences, University of Saskatchewan, Saskatoon), and progesterone-11a-glucuronide${ }^{125}$ I] iodotyramine as tracer (Amersham). Bound ligand was precipitated using $17 \%$ polyethylene glycol 8000 (Sigma Chemical Co.).

\section{Statistical analyses}

Results of progesterone assays were analysed by one-way analysis of variance. Differences between means were determined using Duncan's multiple range test (Steel and Torrie, 1960).

\section{Hormones and chemicals}

Cyclic AMP, forskolin and cholera toxin were purchased from Sigma Chemical Co., FSH (NIADDK-oFSH-17) and LH (NIADDK-oLH-25) were a gift from NIDDK.

\section{Results}

Follistatin gene expression in granulosa cells from small, medium and large follicles

To determine whether follistatin gene expression increases during growth of antral follicles, we measured the abundance

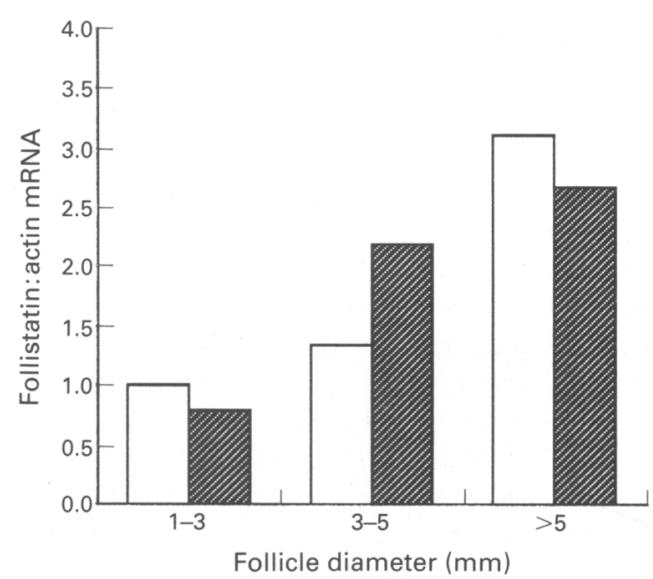

Fig. 1. Follistatin mRNA content in granulosa cells of growing antral follicles. Total RNA was isolated from granulosa cells of small ( $1-3 \mathrm{~mm})$, medium $(3-5 \mathrm{~mm})$, and large $(>5 \mathrm{~mm})$ antral follicles from prepubertal ( $\square$ ) and postpubertal (园) pigs. RNA from pooled granulosa cells of each size class was analysed by slot blot hybridization to [ $\left.{ }^{32} \mathrm{P}\right]$-labelled follistatin and $\gamma$ actin cDNA probes. Data are presented as arbitrary densitometric units for follistatin relative to $\gamma$ actin $\mathrm{mRNA}$, adjusted to a value of 1.0 for the samples from 1 to $3 \mathrm{~mm}$ follicles of prepubertal pigs.

of follistatin mRNA in granulosa cells isolated from small (1-3 mm), medium (3-5 mm) and large $(>5 \mathrm{~mm})$ follicles collected from sows at an abattoir. Slot blot analysis of total cellular RNA collected from granulosa cells from pooled small, medium and large follicles demonstrated that the steady-state concentrations of follistatin mRNA increased with follicular diameter in both prepubertal and postpubertal sows (Fig. 1).

\section{Regulation of follistatin gene expression in cultured granulosa cells} by gonadotrophins

The effects of gonadotrophins on follistatin gene expression were investigated in serum-free cell culture. Steady-state concentrations of follistatin mRNA increased in granulosa cells treated with $100 \mathrm{ng}$ ovine FSH (o-FSH) $\mathrm{ml}^{-1}$ for $20 \mathrm{~h}$ (Fig. 2a). Both FSH and LH caused dose-dependent increases in follistatin mRNA accumulation in granulosa cells, as determined by laser densitometry of slot blots hybridized to follistatin cDNA probe (Fig. 2a). The viability and appropriate biological function of the cells was demonstrated by the increase in progesterone secretion into the culture medium in response to FSH and LH (Fig. 2b).

Regulation of follistatin gene expression by cAMP, forskolin and cholera toxin

Treatment of granulosa cells with $10 \mu \mathrm{mol}$ dibutyryl cAMP $\mathrm{l}^{-1}, 30 \mu \mathrm{mol}$ forskolin $\mathrm{I}^{-1}, 100 \mathrm{ng}$ cholera toxin $\mathrm{ml}^{-1}, 200 \mathrm{ng}$ $\mathrm{FSH} \mathrm{ml}{ }^{-1}$ or $200 \mathrm{ng} \mathrm{LH} \mathrm{ml}^{-1}$ for $20 \mathrm{~h}^{2}$ resulted in increases in follistatin mRNA accumulation by factors of 1.6, 13.7, 3.5, 4.9, and 3.7, respectively (Fig. 3). Dose-dependent stimulation of follistatin mRNA accumulation by dibutyryl cAMP $(30,100$ and $\left.300 \mu \mathrm{mol} \mathrm{l}^{-1}\right)$ and forskolin $\left(3,10\right.$ and $\left.30 \mu \mathrm{mol} \mathrm{l}{ }^{-1}\right)$ was demonstrated by northern blot analysis of granulosa cell RNA, 

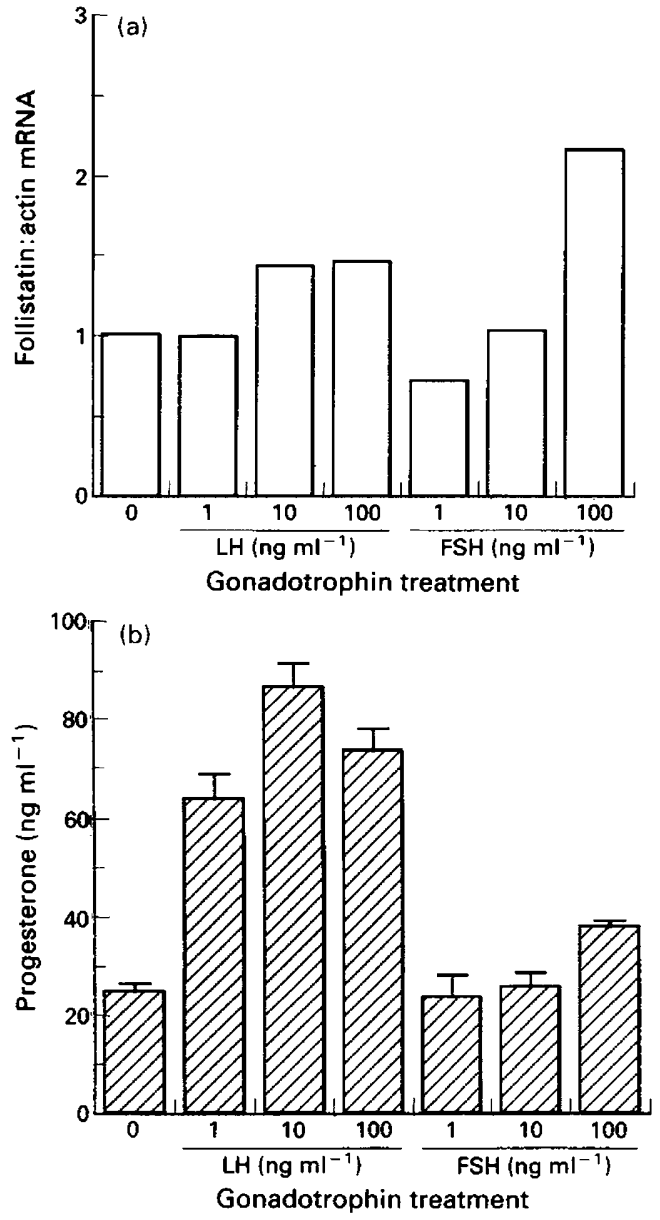

Fig. 2. Effect of FSH and LH on follistatin mRNA accumulation and progesterone secretion from cultured granulosa cells of pigs. (a) Slot blot analysis of RNA ( $6 \mu \mathrm{g}$ per slot) from granulosa cells treated with ovine(o)-FSH, o-LH, or culture medium (control). Blots were hybridized to $\left[{ }^{32} \mathrm{P}\right]$-labelled follistatin and $\gamma$ actin cDNA probes. Data are presented as arbitrary densitometric units for follistatin relative to $\gamma$ actin mRNA, adjusted to a value of 1.0 for negative control cultures. (b) Progesterone concentrations ( $\mathrm{ng} \mathrm{ml}^{-1}$ ) in control culture medium and in cells treated with o-FSH or o-LH (mean \pm SEM, $n=6$ ).

using $15 \mu \mathrm{g}$ of total cellular RNA per lane (Fig. 4a). This experiment was repeated and analysed by slot blot hybridization to follistatin and $\gamma$ actin cDNA probes. Dibutyryl cAMP and forskolin increased follistatin mRNA accumulation in granulosa cells by a factor of 5.2 (cAMP, $300 \mu \mathrm{mol} \mathrm{l}^{-1}$ ) and 4.1 (forskolin, $30 \mu \mathrm{mol} \mathrm{l}^{-1}$ ) compared with untreated cells (Fig. $4 \mathrm{~b})$. The magnitude of induction of follistatin mRNA expression in response to cAMP and forskolin varied between experiments, reflecting possible differences in the populations of cells isolated for each experiment.

\section{Time-dependent regulation of follistatin gene expression by FSH and forskolin}

The time-course of stimulation of follistatin gene expression by FSH and forskolin in cultured granulosa cells was examined. Cells treated with $100 \mathrm{ng} \mathrm{FSH} \mathrm{ml}^{-1}, 10 \mu \mathrm{mol}$ forskolin $\mathrm{l}^{-1}$ or

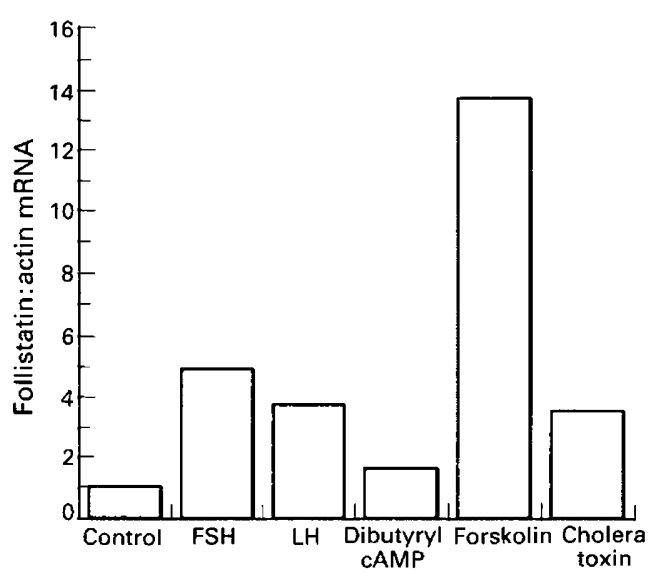

Fig. 3. Stimulation of follistatin mRNA accumulation in porcine granulosa cells by FSH, LH, dibutyryl cAMP, forskolin and cholera toxin. Granulosa cells were treated with $200 \mathrm{ng}$ ovine(o)-FSH ml ${ }^{-1}$, $200 \mathrm{ng} \mathrm{o-LH} \mathrm{ml}{ }^{-1}, 10 \mu \mathrm{mol}$ dibutyryl cAMP $\mathrm{l}^{-1}, 30 \mu \mathrm{mol}$ forskolin $\mathrm{l}^{-1}, 100 \mathrm{ng}$ cholera toxin $\mathrm{ml}^{-1}$ or minimum essential medium (control). Total RNA collected $20 \mathrm{~h}$ after treatment was analysed by slot blot hybridization $\left(6 \mu \mathrm{g}\right.$ per slot) to [ ${ }^{32} \mathrm{P}$-labelled follistatin and $\gamma$ actin cDNA probes. Data represent arbitrary densitometric units for follistatin relative to $\gamma$ actin mRNA, adjusted to a value of 1.0 for the negative control cultures.

culture medium (MEM) (negative control) were harvested for RNA isolation at $0,12,24,48$ and $72 \mathrm{~h}$ after the addition of treatments (Fig. 5a). Accumulation of follistatin mRNA induced by FSH increased by factors of 2.7 (12 h), 3.8 ( $24 \mathrm{~h}), 3.4(48 \mathrm{~h})$ and $4.5(72 \mathrm{~h})$ compared with the mean negative control at zero time. Similarly, forskolin induced follistatin mRNA accumulation by factors of 3.4 (12 h), $3.6(24 \mathrm{~h}), 7.9(48 \mathrm{~h})$ and $15.5(72 \mathrm{~h})$ compared with control values at zero time. The induction of follistatin gene expression over $72 \mathrm{~h}$ was accompanied by a corresponding increase in progesterone accumulation in the culture medium in response to both FSH and forskolin (Fig. 5b).

\section{Discussion}

Using a full-length porcine follistatin cDNA probe generated by RT-PCR of ovarian RNA, we showed that follistatin mRNA concentrations in granulosa cells increased during growth of antral follicles in the pig. Changes in follistatin gene expression during follicular development have been demonstrated in rat ovaries by in situ hybridization (Nakatani et al., 1991). These authors detected a strong signal for follistatin mRNA in all antral follicles, except those undergoing atresia. The present study shows that follistatin mRNA is present in granulosa cells of porcine antral follicles, and also demonstrates that the abundance of follistatin mRNA increases with follicular diameter. Similarly, Shukovski et al. (1992) recently reported that steady-state concentrations of follistatin mRNA increase with follicular diameter in granulosa cells from bovine antral follicles, reaching a maximum in preovulatory follicles. This finding suggests that follistatin expression may be associated with the process of granulosa cell differentiation or proliferation during follicular maturation in vivo. 

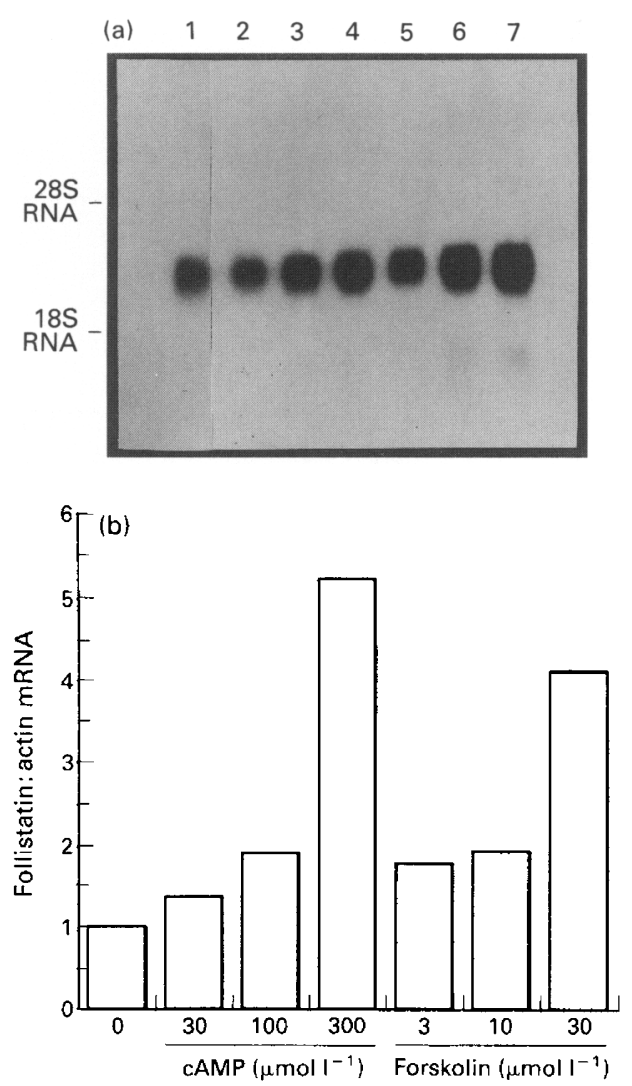

Fig. 4. Dose-dependent stimulation of follistatin mRNA accumulation by dibutyryl cAMP and forskolin. (a) Porcine granulosa cells were treated with dibutyryl cAMP $\left(30,100,300 \mu \mathrm{mol} 1^{-1}\right.$; lanes 2,3 and 4), forskolin (3, 10, $30 \mu \mathrm{mol} \mathrm{l}^{-1}$; lanes 5, 6 and 7), or minimum essential medium (MEM) (control; lane 1) for $20 \mathrm{~h}$. Total RNA (15 $\mu \mathrm{g}$ per lane) was analysed by northern blot and hybridized to $\left[{ }^{32} \mathrm{P}\right]-$ labelled follistatin cDNA probe. (b) Granulosa cells were treated with dibutyryl cAMP $\left(30,100,300 \mu \mathrm{mol} \mathrm{I}{ }^{-1}\right)$, forskolin $(3,10,30 \mu \mathrm{mol}$ $\mathrm{l}^{-1}$ ), or MEM (control) for $20 \mathrm{~h}$. Total RNA was analysed by slot blot hybridization $\left(6 \mu \mathrm{g}\right.$ per slot) to $\left[{ }^{32} \mathrm{P}\right.$-labelled follistatin and $\gamma$ actin cDNA probes. Data represent arbitrary densitometric units for follistatin relative to $\gamma$ actin mRNA, adjusted to a value of 1.0 for the negative control culture.

In this study, we also demonstrated the regulation of follistatin gene expression in cultured porcine granulosa cells in response to gonadotrophins and agents that stimulate intracellular cAMP production. Using a primary porcine granulosa cell model, we found that FSH stimulated follistatin mRNA accumulation in a dose- and time-dependent manner. The cells used for primary culture were isolated from follicles with a diameter of $3-5 \mathrm{~mm}$, to reduce the possible variability associated with differences in the stage of granulosa cell differentiation at the start of culture (Channing, 1970). The time course of stimulation of follistatin mRNA by FSH indicated that maximal stimulation occurs after chronic exposure to FSH. Prolonged exposure to FSH also resulted in increased progesterone secretion, which is evidence of granulosa cell differentiation. This suggests that granulosa cell differentiation is associated with increased expression of follistatin mRNA. Although a causative role for follistatin in this process has not been unequivocally established, the studies of Shukovski $e t$ al.
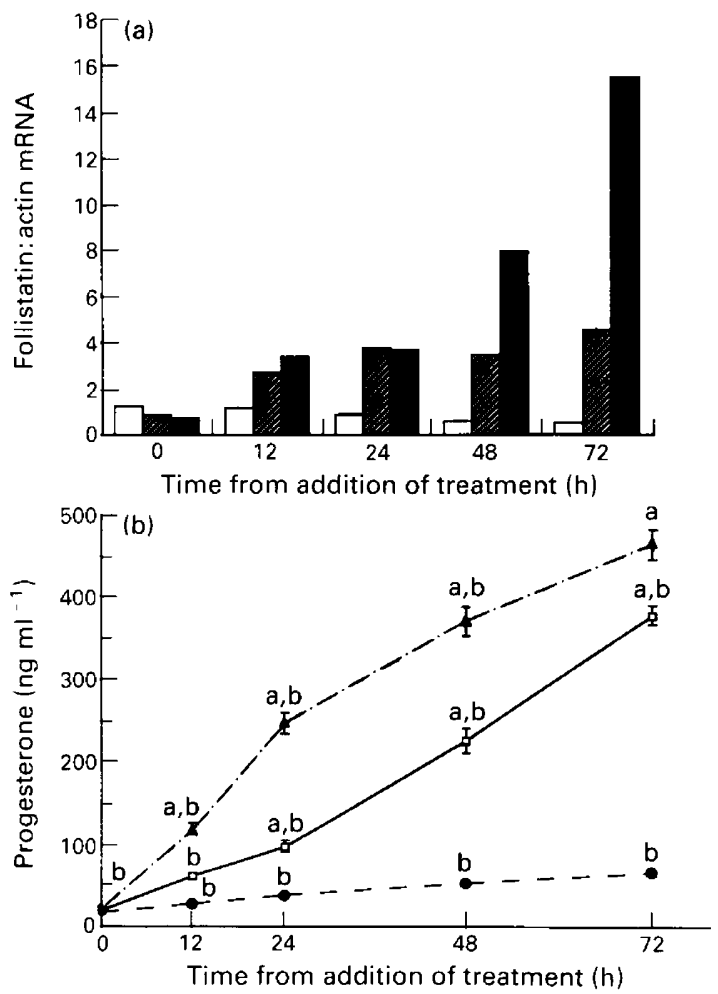

Fig. 5. Time-dependent stimulation of follistatin mRNA and progesterone accumulation by FSH and forskolin. Porcine granulosa cells were treated with $100 \mathrm{ng}$ ovine(o)-FSH ml ${ }^{-1}, 10 \mu \mathrm{mol}$ forskolin $\mathrm{l}^{-\mathrm{I}}$, or minimum essential medium (MEM) (see Materials and Methods section for constituents) (control) for $0,12,24,48$ or $72 \mathrm{~h}$. (a) Total RNA was analysed by slot blot hybridization ( $6 \mu \mathrm{g}$ per slot) to $\left[{ }^{32} \mathrm{P}\right]$-labelled follistatin and $\gamma$ actin cDNA probes. Data represent arbitrary densitometric units for follistatin relative to $\gamma$ actin mRNA, adjusted to a value of 1.0 for the negative control cultures $(\square$, control; 圈, FSH; $\mathbf{\square}$, forskolin). (b) Progesterone concentrations ( $\mathrm{ng} \mathrm{ml}^{-1}$ ) in culture medium (mean $\pm \mathrm{SEM}, n=6$ ). Different letters above the points indicate significantly different means $(P<0.05)(0$, control; $\square$, FSH; $\Delta$, forskolin).

(1991) suggest that follistatin can induce luteinization of bovine granulosa cells in vitro.

Effects of FSH on follistatin mRNA accumulation have not previously been demonstrated in cultured porcine granulosa cells. However, in primary cultures of bovine granulosa cells, the secretion of follistatin increased in response to bovine FSH by a factor of 2-3 compared with untreated controls (Klein et al., 1991). In addition, the effect of FSH on follistatin secretion was dose dependent: maximal stimulation occurred at a dose of $20 \mathrm{ng} \mathrm{ml}^{-1}$ (Klein et al., 1991). Using an activin-binding assay, Saito et al. (1991) showed that equine FSH stimulated follistatin secretion by rat granulosa cells in a dose-dependent manner after $72 \mathrm{~h}$ incubation, with a maximal effective dose of $30 \mathrm{ng} \mathrm{ml}^{-1}$. Our results demonstrate that in cultured porcine granulosa cells, gonadotrophins exert their effect by stimulating follistatin mRNA accumulation, which could be accounted for either by increased transcription or increased mRNA stability. This finding does not exclude a concomitant effect of gonadotrophins on follistatin translation. 
LH also caused a dose-dependent increase in follistatin mRNA accumulation. Although the effects of LH on follistatin mRNA concentration in porcine granulosa cells have not previously been reported, these results are inconsistent with two studies in which $\mathrm{LH}$ had no effect on secretion of follistatin in bovine (Klein et al., 1991) or rat (Saito et al., 1991) granulosa cells. This disparity may be the result of differences in the model systems. For instance, granulosa cells from immature, oestrogen-primed rats do not respond to $\mathrm{LH}$ unless previously stimulated with FSH to induce expression of $\mathrm{LH}$ receptors (Hsueh et al., 1984). In contrast, the primary cultures of porcine granulosa cells used in the present experiments secreted large amounts of progesterone in response to $\mathrm{LH}$ alone. Since both FSH and $\mathrm{LH}$ are considered to act principally by activation of adenylyl cyclase and stimulation of intracellular cAMP (Marsh, 1976), either gonadotrophin should stimulate cAMPdependent follistatin gene expression, provided that the appropriate receptors are present.

The stimulation of follistatin mRNA concentration by gonadotrophins resulted in an increase between 1.5 and 5 times that of control in different experiments. Similarly, induction of follistatin gene expression by forskolin varied between 4 - and 13.7-fold increases. The variability in responses to the same conditions between experiments may be a result of variability in cell populations. Since freshly isolated cells were used for each experiment, differences in age and genetic background of the donor pigs could contribute to the variable follistatin gene induction. We found that within a cell culture experiment, the stimulation of follistatin gene induction by a particular drug is very consistent.

Many of the effects of FSH and LH on the differentiation of cultured granulosa cells can be mimicked by treating the cells with agents that increase intracellular cAMP concentration (Knecht et al., 1983). We tested the hypothesis that follistatin gene expression is regulated by CAMP-dependent mechanisms. Forskolin, cholera toxin and the cAMP analogue dibutyryl cAMP all induced follistatin mRNA accumulation in porcine granulosa cells. Moreover, both dibutyryl cAMP and forskolin induced dose-dependent stimulation of follistatin mRNA accumulation. In addition, forskolin induced a time-dependent stimulation of follistatin mRNA accumulation. Klein et al. (1991) showed that 8-bromo-cAMP stimulated follistatin secretion from cultured bovine granulosa cells. The results of the present investigation support the hypothesis that cAMPdependent mechanisms stimulate follistatin expression at least partly at the pre-translational level. We also showed that phorbol 12-myristate 13-acetate, a protein kinase C activator, and epidermal growth factor acutely stimulate follistatin mRNA expression in cultured granulosa cells (Lindsell et al, 1993), suggesting that the follistatin gene may be regulated by multiple pathways in granulosa cells.

The role of follistatin in reproduction is still unclear. Although it was isolated by virtue of its inhibin-like activity on pituitary cells, its role as a negative regulator of FSH secretion in vivo has not been conclusively demonstrated. There is some evidence that follistatin may downregulate FSH secretion in vivo, since injection of rats with native or recombinant porcine follistatin reduces circulating FSH concentrations (Inouye et al., 1991). However, the link between follistatin synthesis and fluctuations in FSH concentrations during the oestrous cycle has not been rigorously established. Stimulation of ovarian follistatin mRNA concentration by gonadotrophins in vivo has been observed in rats (Shimasaki et al., 1989) and has been confirmed in our laboratory (data not shown). The present study shows that gonadotrophins also upregulate follistatin gene expression in cultured porcine granulosa cells. A primary effect of gonadotrophins is to induce differentiation of cultured granulosa cells, suggesting that follistatin gene expression increases as the cells differentiate. In fact, our studies showed an accumulation of follistatin mRNA up to $72 \mathrm{~h}$ after treatment, accompanied by increased progesterone accumulation in the culture medium. It is possible that the progesterone produced by the cultured granulosa cells under the influence of cAMP may be acting as an autocrine regulator of follistatin gene expression. Our finding that follistatin mRNA concentration increases with follicular diameter in pigs suggests that follistatin gene expression may also be upregulated during granulosa cell differentiation in vivo.

We conclude that gonadotrophins and CAMP can stimulate follistatin mRNA accumulation in cultured porcine granulosa cells, which indicates that increased follistatin gene expression may be associated with granulosa cell differentiation in vitro.

The authors would like to thank the National Hormone and Pituitary Program, NIDDK, for generously providing us with $\mathrm{LH}$ and FSH used in this study. They also thank Y. Y. Shi and A. KozielAndrzejewska for their assistance with granulosa cell culture, and P. Ward for synthesizing the oligonucleotides. Experiments were funded by MRC operating grant no. MT11018 and NSERC strategic grant no. 101265 to B. D. Murphy. C. E. Lindsell was supported by a fellowship from the Medical Research Council of Canada.

\section{References}

Broxmeyer HE, Lu L, Cooper S, Schwall RH, Mason AJ and Nikolics K (1988) Selective and indirect modulation of human multipotential and erythroid hematopoietic progenitor cell proliferation by recombinant human activin and inhibin Proceedings of the National Academy of Sciences USA 85 90529056

Channing CP (1970) Effect of stage of the estrous cycle and gonadotropins upon luteinization of porcine granulosa cells in culture Endocrinology 87 156-164

DePaolo LV, Bicsak TA, Erickson GF, Shimasaki S and Ling N (1991) Follistatin and activin: A potential intrinsic regulatory system within diverse tissues Proceedings of the Society of Experimental Biology and Medicine 198 500-512

Esch FS, Shimasaki S, Mercado M, Cooksey $K$, Ling N, Ying S, Ueno N and Guillemin R (1987) Structural characterization of follistatin: A novel folliclestimulating hormone release-inhibiting polypeptide from the gonad Molecular Endocrinology $1849-855$

Eto Y, Tsuji Y, Takezawa M, Takano S, Yokogawa Y and Shibai H (1987) Purification and characterization of erythroid differentiation factor (EDF) isolated from human leukemia cell line Biochemical and Biophysical Research Communication 142 1095-1103

Gospodarowicz D and Lau K (1989) Pituitary follicular cells secrete both vascular endothelial growth factor and follistatin Biochemical and Biophysical Research Communications 165 292-298

Hsueh AJW, Adashi EY, Jones PBC and Welsh TH (1984) Hormonal regulation of the differentiation of cultured ovarian granulosa cells Endocrine Reviews 5 76-127

Inouye S, Guo Y, DePaolo L, Shimonaka M, Ling N and Shimasaki S (1991) Recombinant expression of human follistatin with 315 and 288 amino acids: Chemical and biological comparison with native porcine follistatin Endocrinology 129 815-822

Kaiser M, Gibori G and Mayo KE (1990) The rat follistatin gene is highly expressed in decidual tissue Endocrinology 126 2768 2770 
Kingston RE (1989) Guanidinium method for total RNA preparation Current Protocols in Molecular Biology pp 4.2.1-4.2.5 Eds FM Ausubel, R Brent, RE Kingston, DD Moore, JG Seidman, JA Smith and K Struhl. John Wiley and Sons, New York

Klein R, Robertson DM, Shukovski L, Findlay JK and de Kretser DM (1991) The radioimmunoassay of follicle-stimulating hormone (FSH)-suppressing protein (FSP): Stimulation of bovine granulosa cell FSP secretion by FSH Endocrinology 128 1048-1056

Knecht M, Ranta T and Catt KJ (1983) Granulosa cell differentiation in vitro: Induction and maintenance of follicle-stimulating hormone receptors by adenosine 3',5'-monophosphate Endocrinology 113 949-956

Kogawa K, Nakamura T, Sugino K, Takio K, Titani K and Sugino H (1991) Activin-binding protein is present in pituitary Endocrinology 128 1434-1440

Lindsell CE, Misra V and Murphy BD (1993) Regulation of follistatin messenger ribonucleic acid in porcine granulosa cells by epidermal growth factor and the protein kinase-C pathway Endocrinology 132 1630-1636

Ling N, Ying S-Y, Ueno N, Shimasaki S, Esch F, Hotta M and Guillemin R (1986) Pituitary FSH is released by a heterodimer of the $\beta$-subunits from the two forms of inhibin Nature 321 779-782

Marsh JM (1976) The role of cyclic AMP in gonadal steroidogenesis Biology of Reproduction 14 30-53

Michel U, Albiston A and Findlay JK (1990) Rat follistatin: Gonadal and extragonadal expression and evidence for alternative splicing Biochemical and Biophysical Research Communications 173 401-407

Nakamura T, Takio K, Eto Y, Shibai H, Titani K and Sugino H (1990) Activinbinding protein from rat ovary is follistatin Science 247 836-838

Nakatani A, Shimasaki S, DePaolo LV, Erickson GF and Ling N (1991) Cyclic changes in follistatin messenger ribonucleic acid and its protein in the rat ovary during the estrous cycle Endocrinology $129603-611$

Rajkumar K, Malinek J and Murphy BD (1985) Effect of lipoproteins and luteotrophins on progesterone accumulation by luteal cells from the pregnant pig Steroids 45 119-134

Robertson DM, Klein R, de Vos FL, McLachlan RI, Wettenhall REH, Hearn MTW, Burger HG and de Kretser DM (1987) The isolation of polypeptides with FSH-suppressing activity from bovine follicular fluid which are structurally different to inhibin Biochemical and Biophysical Research Communications 149 744-749
Saito S, Nakamura T, Titani K and Sugimo H (1991) Production of activinbinding protein by rat granulosa cells in vitro Biochemical and Biophysical Research Communications 176 413-422

Sambrook J, Fritsch EF and Maniatis T (1989) Molecular Cloning: A Laboratory Manual (2nd edn) pp 743-752. Cold Spring Harbor Laboratory Press, New York

Schubert D, Kimura H, La Corbiere M, Vaughan J, Karr D and Fischer WH (1990) Activin is a nerve cell survival molecule Nature 344 868-870

Shimasaki S, Koga M, Esch F, Cooksey K, Mercado M, Koba A, Ueno N, Ying S, Ling $N$ and Guillemin $\mathbf{R}$ (1988) Primary structure of the human follistatin precursor and its genomic organization Proceedings of the National Academy of Sciences USA 85 4218-4222

Shimasaki S, Koga M, Buscaglia ML, Simmons DM, Bicsak TA and Ling N (1989) Follistatin gene expression in the ovary and extragonadal tissues Molecular Endocrinology 3 651-659

Shimonaka M, Inouye S, Shimasaki S and Ling N (1991) Follistatin binds to both activin and inhibin through the common beta subunit Endocrinology 128 3313-3315

Shukovski L, Findlay JK and Robertson DM (1991) The effect of folliclestimulating hormone-suppressing protein or follistatin on luteinizing bovine granulosa cells in vitro and its antagonistic effect on the action of activin Endocrinology 129 3395-3402

Shukovski L, Zhang ZW, Michel U and Findlay JK (1992) FSH-suppressing protein (FSP) mRNA expression in bovine ovarian tissues Joumal of Reproduction and Fertility 95 861-867

Steel RGD and Torrie JH (1960) Principles and Procedures of Statistics: A Biometrical Approach. pp 99-109 McGraw-Hill, New York

Ueno N, Ling N, Ying S-Y, Esch F, Shimasaki S and Guillemin R (1987) Isolation and partial characterization of follistatin: a single-chain $M_{\mathrm{r}} 35,000$ monomeric protein that inhibits the release of follicle-stimulating hormone Proceedings of the National Academy of Sciences USA 84 8282-8286

Van den Eijnden-van Raaij AJM, van Achterberg TAE, van der Kruijssen CMM, Piersma AH, Huylebroeck D, de Laat SW and Mummery CL (1991) Differentiation of aggregated murine P19 embryonal carcinoma cells is induced by a novel visceral endoderm-specific FGF-like factor and inhibited by activin A Mechanisms of Development 33 157-166 